IRA-International Journal of Education \&

Multidisciplinary Studies

ISSN 2455-2526; Vol.17, Issue 02 (Q2, 2021)

Pg. no. 80-84.

IRA Academico Research

\title{
Exploration of Business English Talents Training in Colleges and Universities
}

Li Yan

School of Foreign Language, Yangtze University, Jingzhou, Hubei, P. R. China.

Type of Work: Peer Reviewed.

DOI: 10.21013/jems.v17.n2.p6

DOI URL: https://dx.doi.org/10.21013/jems.v17.n2.p6

\section{How to cite this paper:}

Yan, L. (2021). Exploration of Business English Talents Training in Colleges and Universities. IRA-International Journal of Education \& Multidisciplinary Studies (ISSN 2455-2526), 17(2), 80-84. DOI: https://dx.doi.org/10.21013/jems.v17.n2.p6

(C) IRA Academico Research.

(cc) Er-nc 4.0 International License subject to a proper citation to the publication source of the work.

Disclaimer: The scholarly papers as reviewed and published by IRA Academico Research are the views and opinions of their respective authors and are not the views or opinions of IRA Academico Research. IRA Academico Research disclaims any harm or loss caused due to the published content to any party.

IRA Academico Research is an institutional publisher member of Publishers International Linking Association Inc. (PILA-CrossRef), USA. IRA Academico Research is an institutional signatory to the Budapest Open Access Initiative. Hungary advocating the open access of scientific and scholarly knowledge. IRA Academico Research is a registered content provider under Open Access Initiative Protocol for Metadata Harvesting (OAI-PMH).

The journal is indexed \& included in WorldCat Discovery Service (USA), CrossRef Metadata Search (USA), WorldCat (USA), OCLC (USA), Open J-Gate (India), EZB (Germany) Scilit (Switzerland), Airiti (China), Bielefeld Academic Search Engine (BASE) of Bielefeld University, Germany, PKP Index of Simon Fraser University, Canada. 


\section{ABSTRACT}

With the further development of economic globalization and information technology, e-commerce has won great support from enterprises. Meanwhile, cross-border e-commerce has broken the traditional form of trade, greatly saving trade costs for enterprises. Therefore, with the rapid growth of cross-border e-commerce, foreign companies and e-commerce enterprises have an increasingly urgent demand for business English talents. So it is necessary for colleges and universities to explore a new business English training mode to train some talents who can better promote economic development based on China's economic demand.

Keywords: Cross-border E-commerce; Business English; Talent Training Mode

\section{Introduction}

As economic globalization and information integration develop continuously, international trade and exchanges become more and more frequent, thus leading to an even more urgent demand for application-oriented business English talents. Wang Lifei (2015:3-4) pointed out, "The internationalization of China's economy is faced with a huge shortage of talents, while enterprises wanting to go out are in urgent need of a large number of interdisciplinary compound professionals who are familiar with overseas investment, law, finance, trade, asset management, operation management, marketing, public relations and cultural integration."

Business English education in China has a history of more than 60 years, and the formal establishment of the business English undergraduate program has greatly promoted the development of business English. (Sun Ya, Wang Lifei, 2013:48). Nowadays, the training mode of college business English talents is still influenced by the traditional teaching modes and concepts and restricted by teaching conditions so that colleges emphasize more on theory and neglect practice in business English teaching. (Lin Yining,2017:303) In the course of business English teaching, Teachers use more traditional teaching methods and concepts, and students are not clear about the key and difficult point of this course. Thus, they have always been in a passive position without enthusiasm in business English learning. Although they can master certain amounts of theoretical knowledge in English and business, their practical application skills are still relatively weak, which makes them unable to cope with many practical problems in business activities and then cause a shortage of business English professionals for enterprises. In the face of the rapid development of cross-border e-commerce in China, it is imperative to explore the training model of business English talents.

\section{Problems in Talent Training Mode}

According to the survey of students' business English learning, foreign trade companies and e-commerce companies, the following problems are found in the business English talent training model:

1. The training objectives are not clear enough. Most students do not pay more attention to the relationship between the development of cross-border e-commerce and future employment and do not understand the training goals of business English. The lack of understanding of the training objectives leads to unclear learning objectives, which results in low learning enthusiasm and initiative, and little learning results.

2. The curriculum is not reasonable enough. From a survey of whether students have studied other business-related courses before taking the business English course, it can be seen that the course setting of business English is not reasonable enough, because it is very hard for students to thoroughly 
understand relevant business knowledge without the preparation for relevant business courses.

3. The teaching methods are relatively simple and single. In the survey of the current main business English teaching methods, it can be seen that most teachers still adopt the traditional teaching mode mainly based on explanations in class, which is quite simple and single.

4. The teaching staff is not perfect enough. From the survey of whether business English teachers have sufficient business knowledge and practical skills, it is found that the vast majority of students believe that the business knowledge reserves of business English teachers are still relatively lacking and the practical skills cannot meet the needs of teaching.

5. School-enterprise cooperation is not deep enough. In a survey on whether the school has organized internship training related to business English, it can be seen that the school-enterprise cooperation has not been carried out deeply enough and it has no deep business English training about the practical operation and practical ability for students.

\section{Reform Direction of Talent Training Model}

1. Clear the training objectives. The aims of a college business English major are to foster application-oriented and compound business English professionals who qualify high ideological and political quality, have solid basic knowledge of English language and international business, have a broad international vision and strong business activities ability, be familiar with Chinese and western cultural differences and business etiquette and be able to achieve cross-cultural communication. The student should meet the requirements of all-round development in the aspects of humanistic quality, professional quality and application ability and so on.

2. Optimize the curriculum. The main way to achieve the goal of talent training is the curriculum, so the curriculum is the key point of professional construction. Business English major is to let students understand and master cross-border e-commerce knowledge and international trade knowledge through language media. Business English learners must study other business-related courses besides English. Without relevant business background knowledge to pave the way, students may not be able to deeply understand some business terms and business knowledge in the later course. Therefore, while offering business English courses, business-related courses should also be provided, which can be done in the form of compulsory courses or elective courses.

3. Improve teaching methods. In the questionnaire survey, it is found that the current teaching form is still mainly based on the teacher's explanation, which is relatively simple and single. As for the current problems of insufficient business theory knowledge of cross-border e-commerce talents and poor practical operation ability, traditional teaching methods can no longer meet the needs of the society for talent training. Therefore, it is necessary to improve the teaching methods and ways of business English in colleges and universities, in order to improve the ability of the trained talents. To better accomplishing the teaching goals, some teaching methods can be used, such as classroom culture teaching, multimedia-assisted teaching, topic discussion, scenario simulation and so on.

4. Improve and complete the quality of teaching staff. Teacher team is one of the effective ways to ensure the implementation of the talents training program, and also an important factor to test the effectiveness of teaching. Schools can organize business English teachers to receive training and transition in a purposeful and planned way, or introduce more business English teachers with rich practical experience to enrich the teaching team and strengthen the teaching team through experienced teachers to help the teachers with less experience. It is also possible through school-enterprise cooperation to invite business professionals to give some practical lectures to strengthen communication between teachers 
and enterprises, and to encourage teachers to practice in enterprises and promote teachers actively reflect on teaching and participate in scientific research practices to continuously improve their professional ability and quality, so as to create a team of teachers with rich teaching experience and strong practical ability.

5. Strengthen school-enterprise cooperation. The orientation of the business English course is to cultivate application-oriented business English talents. How to improve students' business practice ability while cultivating their basic English skills? School-enterprise cooperation is one of the effective ways to cultivate talents. It can not only exercise students' practical working ability but also deepen students' understanding of business English courses and improve their learning enthusiasm.

The establishment of off-campus practice bases should make full use of social resources, take the integration of school and society as the prerequisite, improve teaching quality as the primary goal, and take effective measures as the guarantee. It not only follows the laws of higher education but also adapts to the requirements of the market economy system. It is conducive to strengthening practical teaching, cultivating students' practical ability and innovative spirit, and conducive to the construction and improvement of the teaching innovation system, and improving the overall professional level. The internship base should have certain regional and industry representativeness in terms of production, operation, economic development level, resources and ecology, and have advanced technology as well as a good construction and development trend. Besides, it is also able to give necessary guidance and management and provide internship living conditions and facilities for students.

\section{Conclusion}

The "National Standards for the Quality of Undergraduate Teaching for Business English Majors in Colleges and Universities" proposes that business English majors "must cultivate compound and applied talents who are familiar with international business practices, have the ability to use English, business practice and cross-cultural communication."[1] Based on this, this major cultivates high-quality applied talents - who have comprehensive development quality of morality, intelligence, physical education, beauty and labour, have solid basic English language skills, strong cross-cultural business communication and communication skills, proficient international business operations and economic and trade practical skills, be able to meet to need of the regional economy, and can engage in translation, secretarial, and teaching in foreign exchanges, economic and trade institutions, enterprises and service organizations. Focusing on this goal, combined with the needs of the regional economy and social development and the actual situation of students, after multiple inspections and serious demonstrations, we formulate and timely revise the training plan for undergraduate talents in business English, set up professional courses in a more scientific and reasonable manner, and highlight practical teaching links and professional ability training.

Business English is an applied interdisciplinary subject, involving linguistics, psychology, sociology, economics, management, law, pedagogy, computer science and other related disciplines. Currently, Business English is at the crossroads of the transitional reform period. Different universities should set up different business English majors with their own characteristics according to the situation of regions, school and majors instead of based on the same rule.

\section{References:}

[1]. Fan Xiaoyun, Research on the Training of Compound Talents for College Business English Majors [J]. 
IRA-International Journal of Education \& Multidisciplinary Studies Market Modernization, 2007 (36):387-389.

[2]. Lin Tianhu. Three Thoughts on International Business English Teaching [J]. International Business Studies, 2004(1):57-61.

[3]. Lin Yining, Research on the Training Model of College Business English Talents Based on the Network Environment [J].Journal of Jiamusi Vocational College, 2017(2):303. 